\title{
Sea grass surveys in the Eastern part of Lampi Island, in Myanmar
}

\begin{abstract}
Sea grass surveys were conducted in Lampi Island (Marine National Park), Taninthayi Region from 7th Novemver to 9th November 2018. A total of 5 species of sea grasses, namely Cymodocea rotundata Ehrenberg et Hemprich ex Ascherson, Halodule uninervis (Forsskal) Ascherson, H. pinifolia (Miki) den Hartog, Thalassia hemprichii (Ehrenberg) Ascherson, Halophila ovalis(R. Brown) Hooker f. were recorded from the survey sites. Thalassia hemprichii represented as a dominant species along the 3 cross-transects in Wa Kyun Island but not the other 2 study sites, Bo Cho Island and Nyaung Pin Aw on which Cymodocea rotudata predominantly occurred. A total of mean coverage of sea grasses were higher in Bo Cho Island (62.64\%) than the other 2 study sites, Wa kyun $(43.47 \%)$ and Nyaung Pin Aw (54.5\%). Due to the dominance of the species of Thalassia hemprichii with thick rhizomes, the biomass of the below ground of the seagrasses in Wa Kyun Island ( 70.43 gm dry. $\mathrm{wt} \mathrm{m}^{-2}$ ) was much more higher than those of the other 2 study sites, Bo Cho Island (38.49gm dry.wtm ${ }^{-2}$ ) and Nyaung Pin Aw (59.63gm dry.wtm ${ }^{-2}$ ).
\end{abstract}

Keywords: Cymodocea rotundata, Thalassia hemprichii, marine organisms, Lampi Island, sea grasses
Volume 8 Issue 2 - 2019

\author{
Moe Lwin Lwin, ' Yin Yin Htay, ${ }^{2}$ Nay Nan \\ Nandar New, ${ }^{3}$ Phyu Phyu Thin, ${ }^{3}$ Thin Lei Lei \\ Wai, ${ }^{3}$ Sue Murray-Jones, ${ }^{4}$ U Soe Htun ${ }^{5}$ \\ 'Assistant Lecturer, Department of Marine Science, Myeik \\ University, Myanmar \\ ${ }^{2}$ Lecturer, Department of Marine Science, Myeik University, \\ Myanmar \\ ${ }^{3}$ Honours Candidates, Department of Marine Science, Myeik \\ University, Myanmar \\ ${ }^{4}$ Flinders University of SA, Australia \\ ${ }^{5}$ Directors, Marine Science Association, Myanmar
}

Correspondence: Moe Lwin Lwin, Assistant Lecturer Department of Marine Science, Myeik University, Myanmar, Emailmoelwinmyk@gmail.com

Received: April 03, 2019 | Published: April 16,2019

\section{Introduction}

Sea grasses are marine flowering plants that form an importan coastal habitat worldwide. They often occur in vast meadows which provide nurseries, shelter and food for a variety of commercially, recreationally and ecologically important species. Twelve genera and 72 species have been reported worldwide. ${ }^{1,2}$ There are 16 species from Southeast Asia. ${ }^{3}$

Sea grasses occur all along three Coastal Regions of Myanmar (Rakhine, Ayeyarwady Delta and the Gulf of Mottama (Martaban), and Tanintharyi). A total of eleven species of sea grasses has been recorded in Myanmar, including Syringodium isoetifolium (Ascherson) Danty, Cymodocea serrulata (R. Brown) Aschersonet Magnus, C. rotundata Ehrenberg et Hemprich ex Ascherson, Halodule uninervis (Forsskal) Ascherson, H. pinifolia (Miki) den Hartog, Enhalus acoroides(Linnaeus f.) Royle, Thalassia hemprichii (Ehrenberg) Ascherson, Halophila beccarii Ascherson, H. decipiens Ostenfeld, $H$. ovalis (R. Brown) Hooker f. and H. major (Zoll)., ${ }^{411}$ listed Halophila spinulosa (R. Br.) Aschers in Myanmar there are no records for those plants in Myanmar so far.

Sea grasses are known to support many endangered species such as turtles and dugongs. ${ }^{12-14}$ Myanmar people are well aware of the importance of sea grasses, calling sea grasses as Leik-Sar-Phat-Myet, meaning the food of marine turtles. ${ }^{6}$ Myanmar seagrass meadows support five species of marine turtles, all of which are IUCN-listed threatened species; the olive ridley turtle (Lepoidochely olivacea; Vulnerable), loggerhead turtle (Caretta caretta; Vulnerable), green turtle (Chelonia mydas; Endangered), hawksbill turtle (Eretmochelys imbricata; Critically Endangered), and the leatherback turtle (Dermochelys coriacea; Vulnerable). ${ }^{6}$ In addition, the sea grass meadows along the Rakhine Coastal Region are known to serve as important feeding grounds for the sea cow, Dugong dugon, which is listed as Vulnerable on the IUCN Red list. ${ }^{15,16}$
The ecological roles of sea grasses are very important. They filter estuarine and coastal waters of nutrients, contaminants and sediments and are closely linked to other communities such as coral reefs and mangroves. ${ }^{17}$ Moreover, they provide habitats for a wide variety of marine organisms. ${ }^{18,19}$ The relatively high rate of primary production in sea grasses drives detritus-based food chains which helps to support many of these organisms. ${ }^{20}$ Recently, monitoring and ecosystem services of sea grasses have been studied by, ${ }^{21-24}$ In addition, it is worth noting that there has been little focus on the plants themselves especially in genetic, which are important for conservation and management.

The objectives of this surveys are: 1) to know the diversity of sea grasses, and 2) to investigate the coverage and biomass of sea grasses growing in 3 survey sites located in eastern part of Lampi Island Group coastal areas.

\section{Materials and methods}

\section{Study sites}

Sea grass surveys were conducted in 3 study sites of the eastern part of Lampi Island Group, namely Bo Cho Island (Lat $10.66^{\circ}$, Long $98.26^{\circ}$ ), Nyaung Pin Aw of Lampi Island (Lat 10. 68 $8^{\circ}$, Long 98. 34 ${ }^{\circ}$ ), and Wa Kyun Island (Lat $10.72^{\circ}$, Long 98. 29 $9^{\circ}$ (Figure 1), Boakpyin Township, Taninthayi Region, from 6th to 9th November 2018.

\section{Taxonomic studies}

Fresh and live materials of sea grasses growing in three survey sites of Lampi Island were sampled by uprooting the sea grasses with a small trowel. The collections (Figure 2) were washed, cleaned and preserved in 10\% formalin in seawater. Samples of sea grasses were examined mainly on the vegetative characters under a dissecting microscope, and then pressed on herbarium sheets to prepare as voucher specimens for each locality. All specimens were identified using the standard monograph of sea grasses prepared by 
den Hartog. ${ }^{25,26}$ This study followed the classification system used by Fortes. ${ }^{27}$ All voucher specimens were deposited at the Herbarium of the Department of Marine Science, Myeik University, Myanmar.

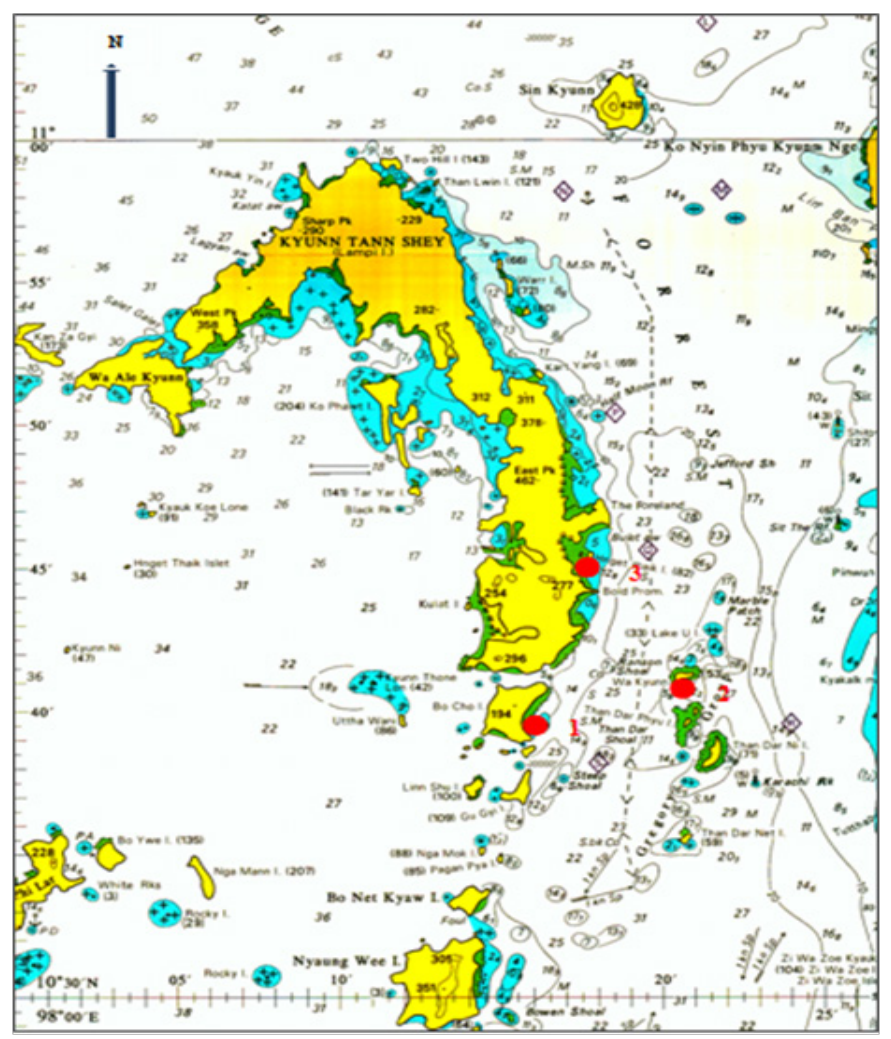

Figure I Map showing the survey sites in red circle: I. Bo Cho Island; 2. Wa Kyun Island; 3. Nyaung Pin Aw.

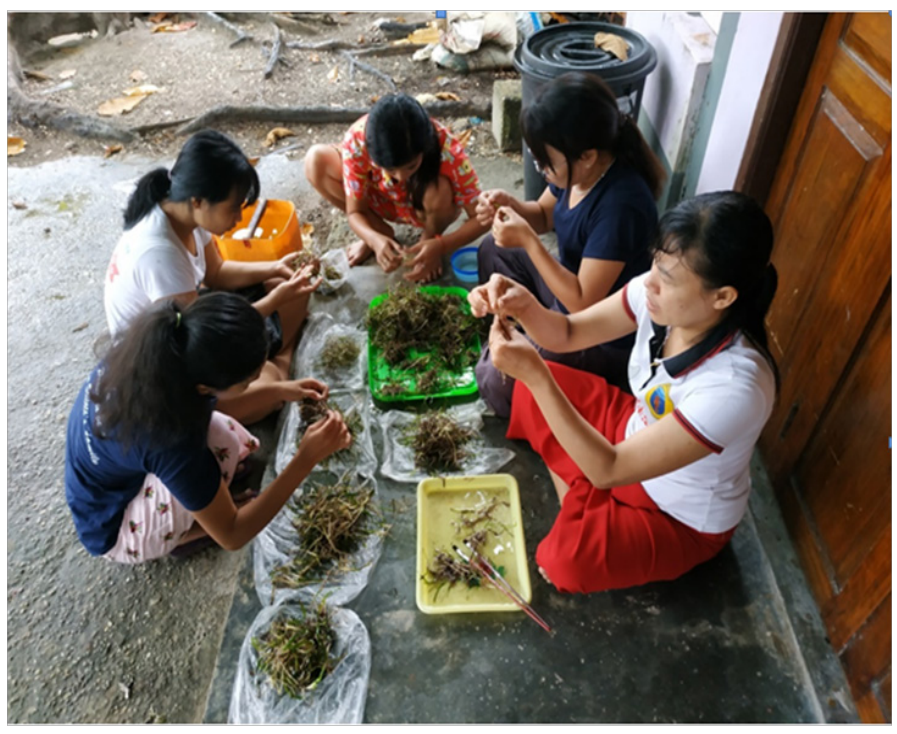

Figure 2 Sorting and identifying the species of seagrass.

\section{Ecological studies}

This study has followed the Sargasso et protocol by Short et al., ${ }^{28,29}$ consisting of three fixed, parallel, $50 \mathrm{~m}$ cross-transects referred to as cross-transects A, B and C, with cross-transect A closest to shore and C most seaward; B, midpoint of these cross-transects were established laid out seaward, perpendicular to the shore. Percentage of sea grasses was visually estimated within 12 randomly place quadrats $\left(50 \mathrm{~cm} \times 50 \mathrm{~cm}, 0.25 \mathrm{~m}^{2}\right)$ along each cross-transect using a photo guide of percent cover (Figure 3). PVC plastic pipe $(7.5 \mathrm{~cm}$ in diameter) was used for coring the sea grass samples. Nine core samples $(0 \mathrm{~m}, 25 \mathrm{~m}$ and $50 \mathrm{~m}$ of each transect, A, B, and C) of sea grasses were collected (Figure 4) and prepared for biomass of sea grasses in dry weight per $\mathrm{m}^{2}$. Sea grass samples were cut into 2 parts as below ground including sheaths, rhizomes and roots of non-photosythetic parts and above ground, green- colored leaf-blade of photosythetic parts.

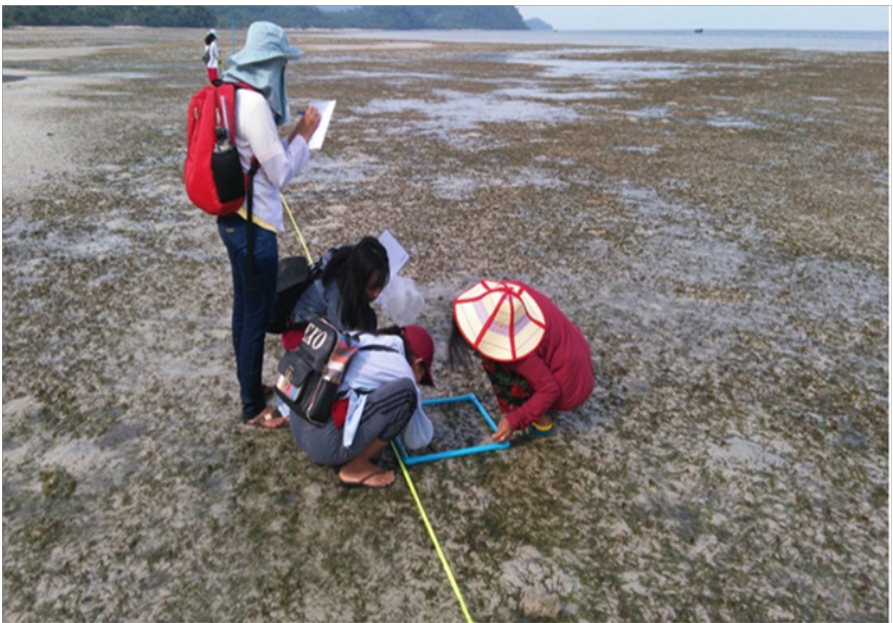

Figure 3 Measuring the percentage cover of seagrass.

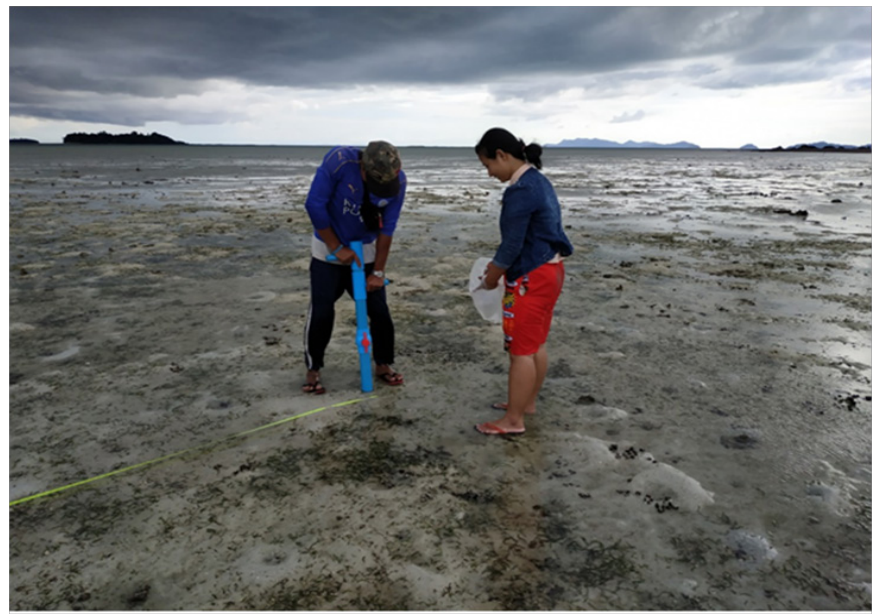

Figure 4 Coring substrate along with seagrass samples to prepare for the biomass of seagrasses.

\section{Results and discussion}

The species of sea grasses occurred in the study sites of the eastern part of the Lampi Island Group could be identified (Figure 5 to Figure 9) in the following key characters:

1. Plants with peddle-shaped leaves. Halophila ovalis

2. Plants with strap-shaped leaves. . .2

3. Leaves tips without 
spines .3

4. Leaves spines.

tips with

Leaves with ligula, rhizones without scars Cymodocea rotundata

6. Leaves without ligula, rhizones with scars. Thalassia hemprichii

7. Leaves tips tri-dentate, central leave vein not split at the tip Halodule uninervis

8. Leaves tips bi-dentate, central leave vein split at the tip H. pinifolia

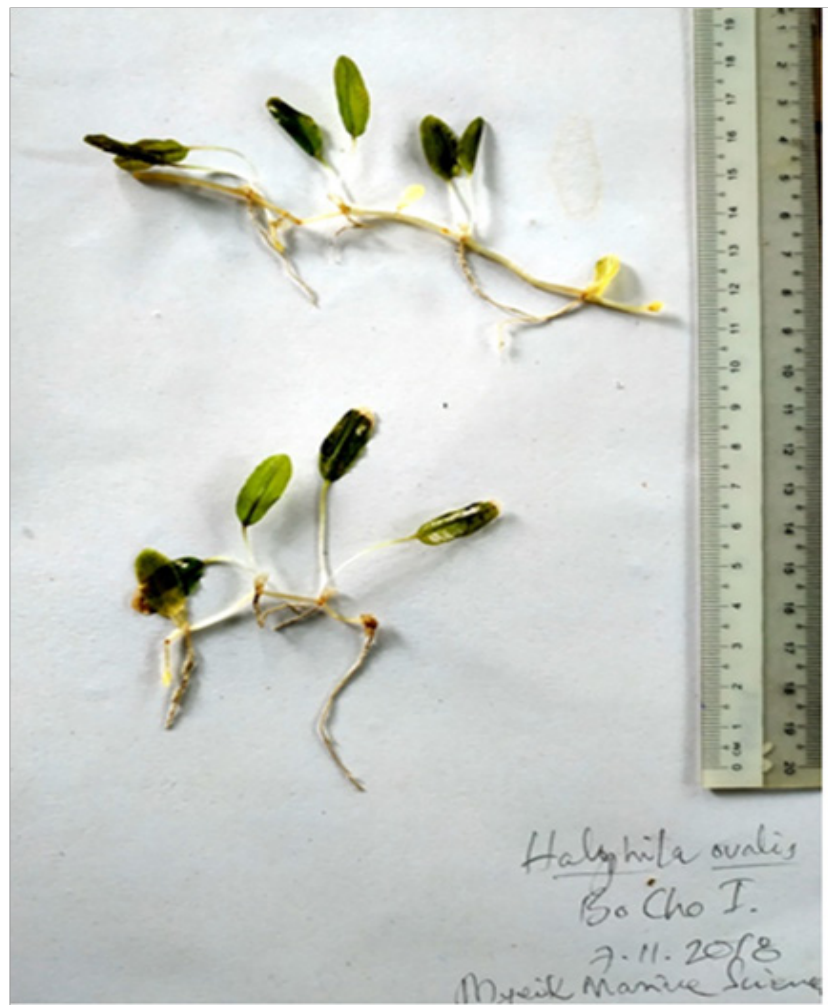

Figure 5 Habit of Halophila ovalis (R. Brown) Hooker f.

Species of sea grasses found in each study site were described along with the coverage of each study site in Table 1. A total of all five species of sea grasses were encountered in Bo Cho Is. and Nyaung Pin Aw whereas a total of three species except for Halodule uninervis and H. pinifolia were found in Wakyun Is.

Soe Htun et al..$^{30}$ described the percentage cover of sea grasses in Bochco Island with $20.89 \%$ in March whereas this survey revealed those of Bochco Island with $62.64 \%$ (Table 1) in November. For this reason, monthly surveys were needed to assess the sustainibility of sea grasses in nature.

The coverage of species of sea grasses along the 3 cross-transects in three study sites of the eastern part of the Lampi Island were shown in Figure 10. Thalassia hemprichii represented as a dominant species along the 3 cross-transects in Wa Kyun Island but not the other 2study sites, Bo Cho Island and Nyaung Pin Aw. However, Cymodocea rotudata predominantly occurred those 2 study sites, except for Wa Kyun Island.

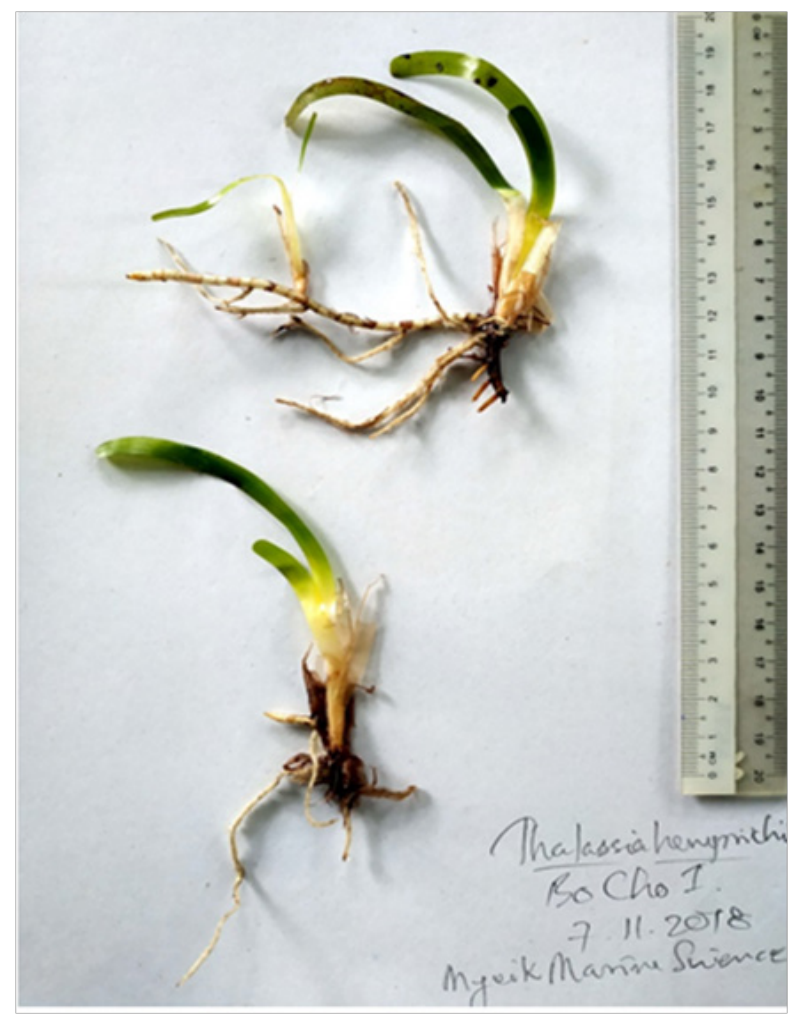

Figure 6 Habit of Thalassia hemprichii (Ehrenberg) Ascherson.

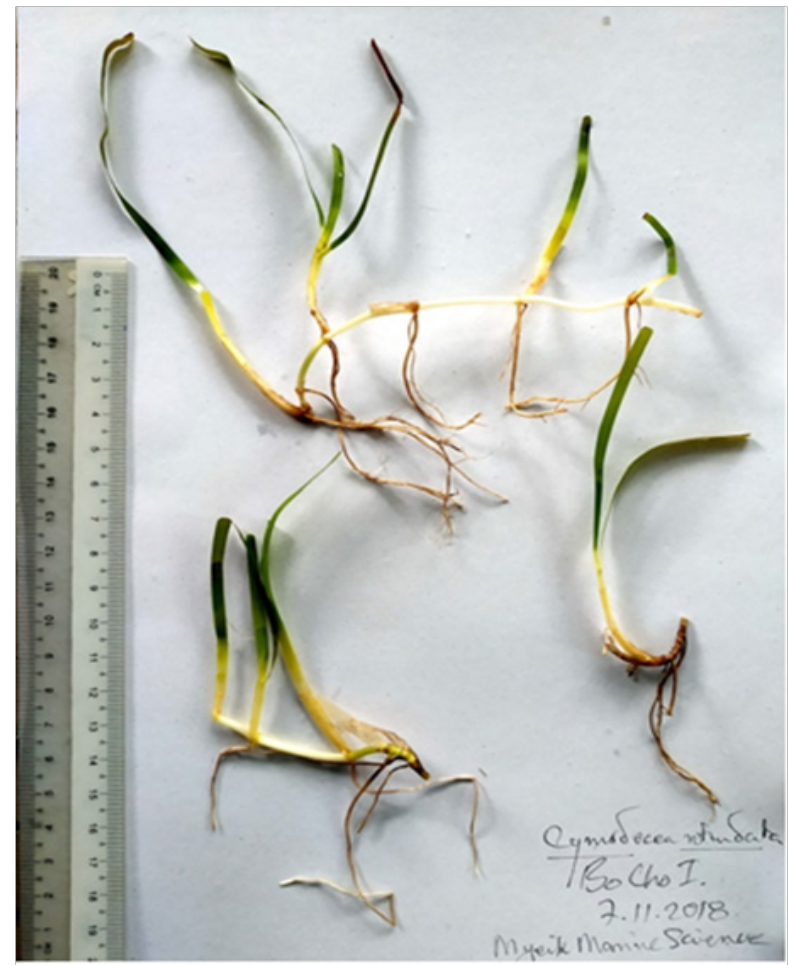

Figure 7 Habit of Cymodocea rotundata Ehrenberg et Hemprich ex Ascherson.

Comparison of mean coverage of sea grasses of the 3crosstransects in three study sites of the eastern part of the Lampi Island were shown in Figure 11 \& Figure 12. In all study sites, the coverage 
of sea grasses of the middle cross-transect B were remarkably higher than cross-transects A and C. A total of mean coverage of sea grasses were higher in Bo Cho Island (62.64\%) than the other 2 study sites, Wa Kyun (43.47\%) and Nyaung Pin Aw (54.5\%). Likewise, comparison of mean biomass of sea grasses of the 3 cross-transects in three study sites of the eastern part of the Lampi Island were shown in Figure 13 \& Figure 14. Due to the dominance of the species of Thalassia hemprichii with thick rhizomes, the biomass of the below ground of the sea grasses in Wa Kyun Island (70.43gm dry.wt $\mathrm{m}^{-2}$ ) was much more higher than those of the other 2 study sites, Bo Cho Island (38.49gmdry. $\mathrm{wt} \mathrm{m}^{-2}$ ) and Nyaung Pin Aw (59.63gmdry.wt $\mathrm{m}^{-2}$ ).

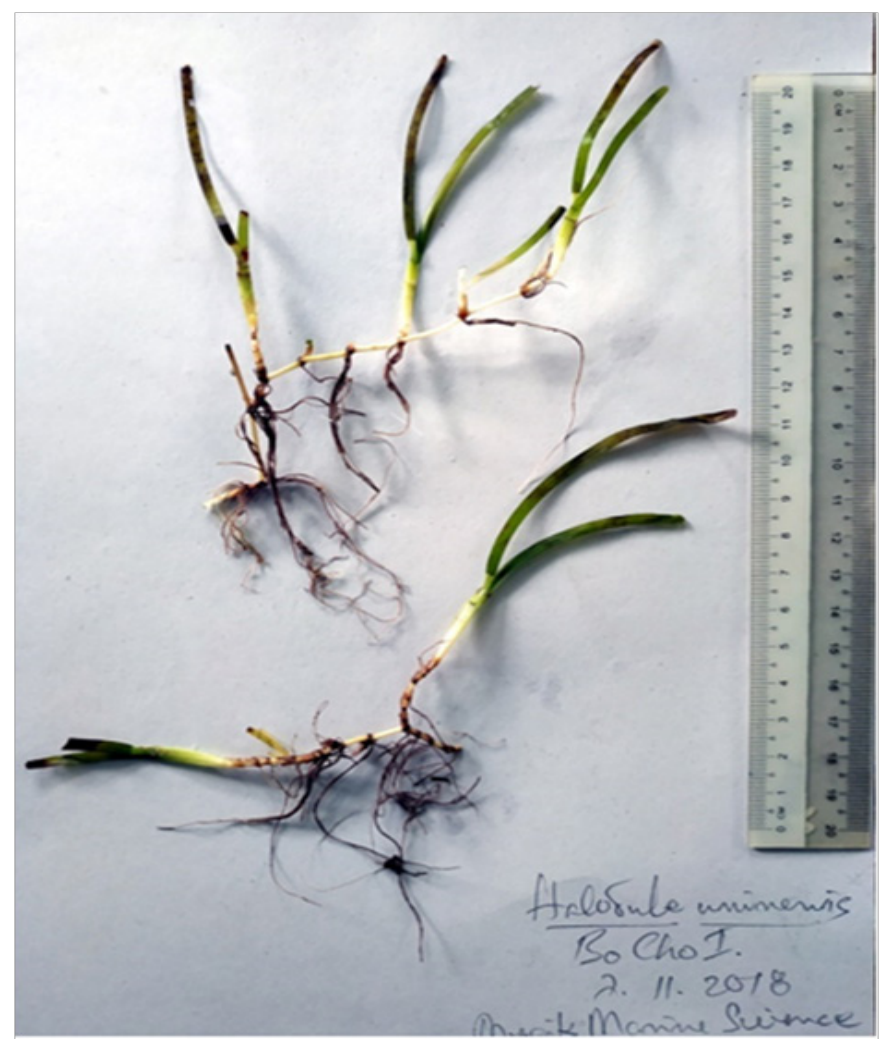

Figure 8 Habit of Halodule uninervis (Forsskal) Ascherson.

The sea grass here is still very pristine and only few researches have been carried out in Myanmar. Thus, capacity building and sea grass monitoring network are very important for this very first few years. Sea grass is well known for its ecosystem service values, they provide home, food and nursery grounds for various marine organisms as well as the important coastal water engineering in the shallow coastal zone. Sea grasses also tie closely with fishermen livelihood; an important ground for small fisheries including crab, sea cucumber, gastropods and others associated faunas.

It is important to note that along this long coastal line and hundreds of islands of Myanmar, there is only one Marine National Park, the Lampi Island. Thus, the understanding of biodiversity and distribution of these marine organisms, sea grass, seaweeds, mangroves and corals, are urgently needed for further management and policy making decision.

The followings are the recommendation and future plans for sea grass conservation and monitoring in Myanmar:

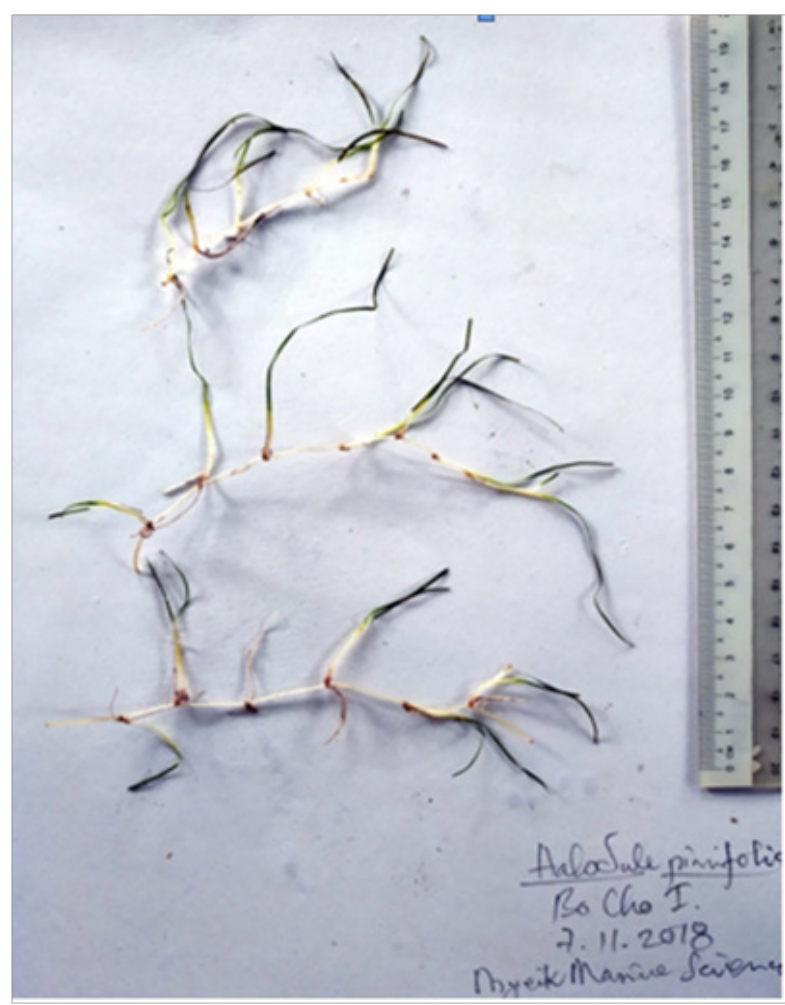

Figure 9 Habit of Halodule pinifolia (Miki) den Hartog.

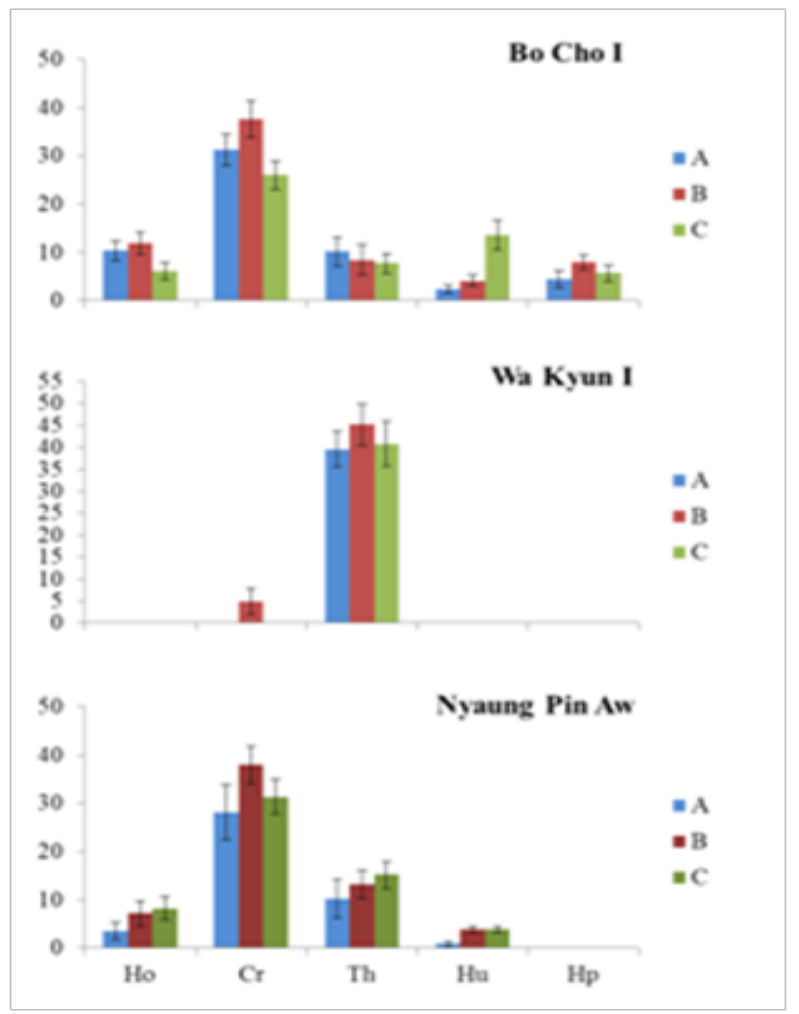

Figure 10 Coverage of species of seagrasses along the cross-transects in three study sites of the eastern part of the Lampi Island. 


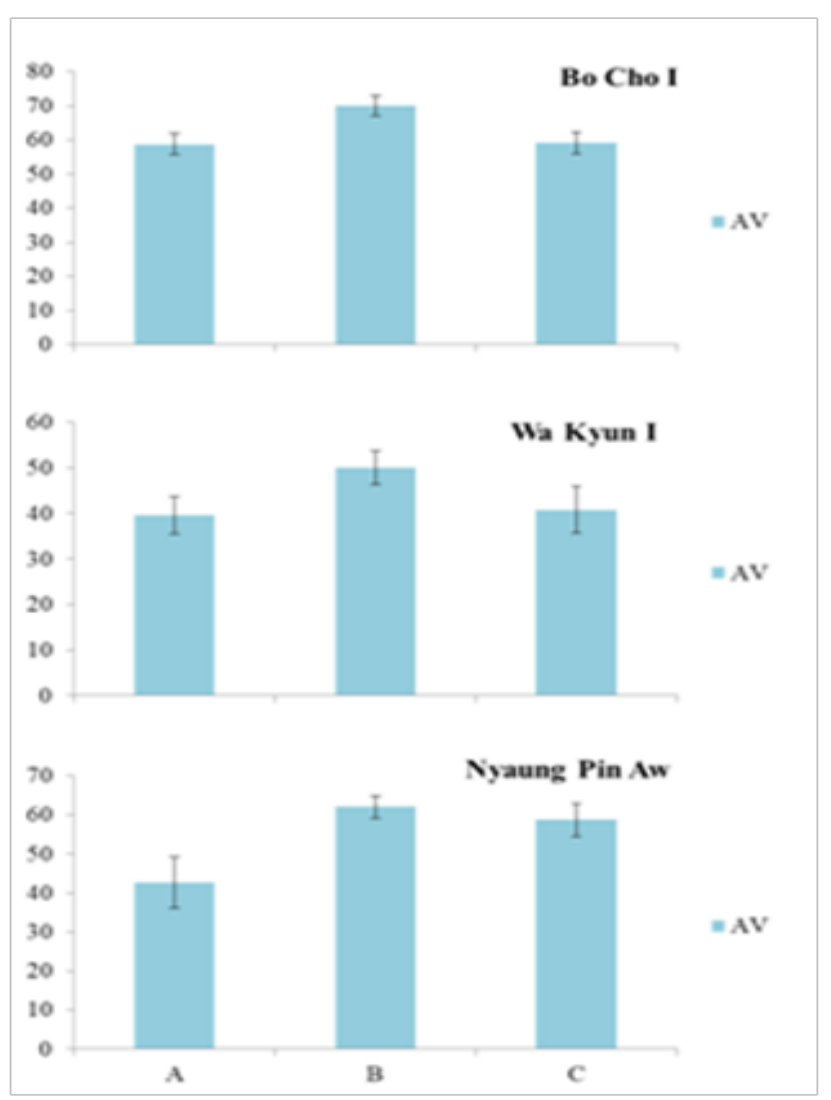

Figure II Coverage of seagrasses along the cross-transects in three study sites of the eastern part of the Lampi Island.

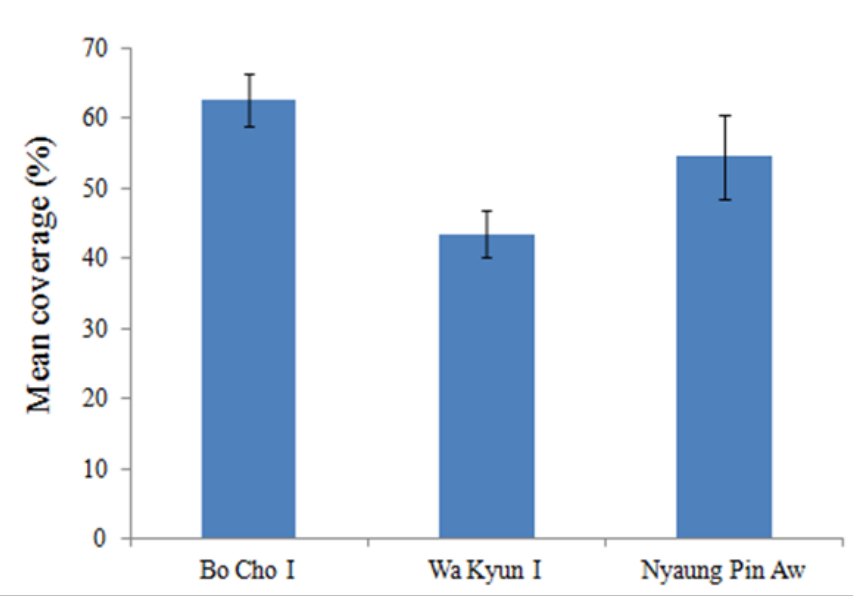

Figure 12 Comparison of mean coverage of seagrasses along the crosstransects in three study sites of the eastern part of the Lampi Island.

a. Carry out more of the capacity building and training on the sea grass conservation and monitoring a few more times by focusing on the region where there are dense of sea grass bed of Lampi Island Group, Myeik Archipelago, Tanintharyi Region. It is important to provide the knowledge on segrass ecology (especially those in ecosystem services, blue carbon and climate change) and increase awareness of the roles of sea grass to the local, government and NGOs through a series of workshop.

b. Setting up a Sea grass monitoring networking in Myanmar through universities and NGOs, having a sharing and discussion networking of their finding and monitoring every year. This would increase the capacity and knowledge of the sea grass in the country. Knowledge sharing between each region will help strengthen their awareness of marine biodiversity and coastal habitats.

c. Develop research collaborations within the region, the study on genetic of seagrass, could provide the important information for further management and policy making such as MPA. In a smaller scale, only the Myeik Archipelago, it would be interesting to investigate the genetic source and sink of the seagrass or other marine organisms in those islands, it provides the important information for further management and conservation. This area can be used and developed as a marine station and used as a model for further studies on marine related field of the country.

d. Sea grass and other coastal habitats such as corals and mangrove should be well surveyed, assessed and mapped. This would provide important baseline information for further management, which is very important for Myanmar. These surveys enhance the management of conservation program for the sustainability of sea grasses in future.

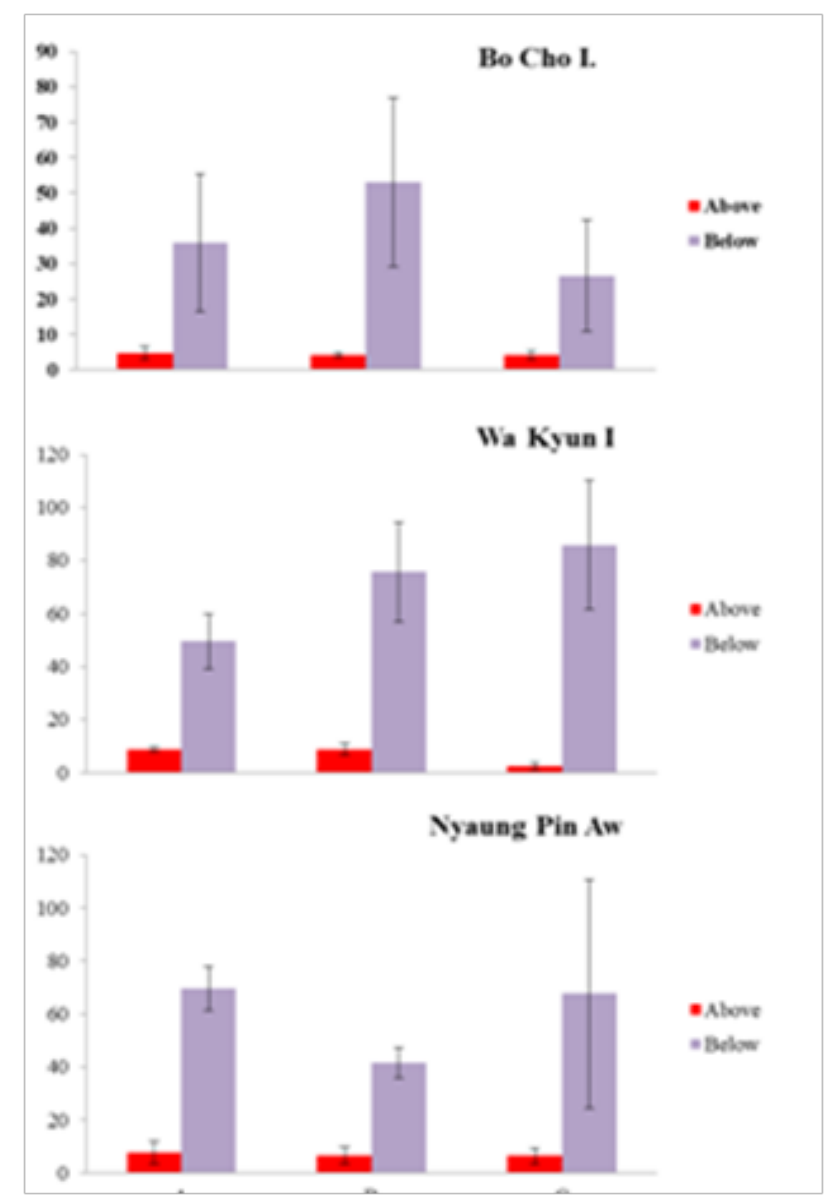

Figure I 3 Biomass of sea grasses along the cross-transects in three study sites of the eastern part of the Lampi Island. 


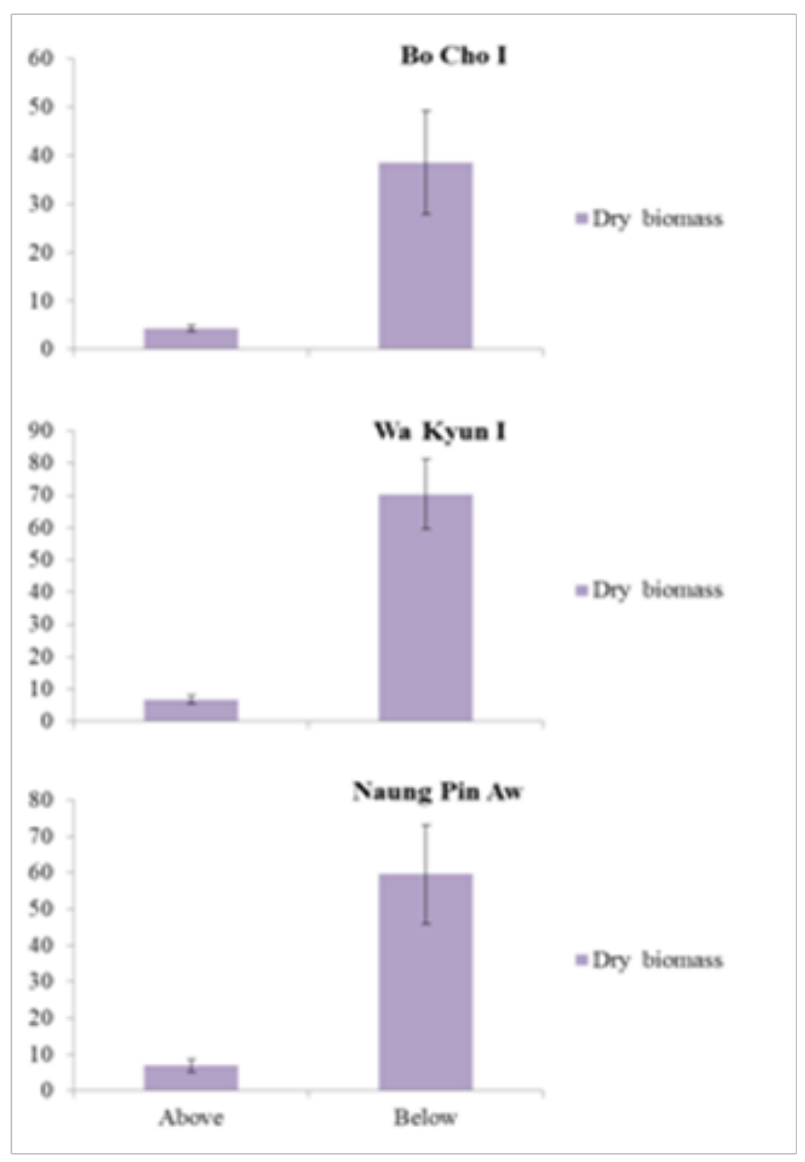

Figure 14 Comparison of biomass of sea grasses in three study sites of the eastern part of the Lampi Island.

\section{Acknowledgments}

We are indebted to Dr Nyo Tun, Professor, Head of Department of Marine Science, and Rector and Administration Board members of Myeik University for their kind permission to conduct this sea grass surveys in the eastern part of the Lampi island, Marine National Park of Myanmar and U Khin Maung Htwe, living in Makyone Galet Village, Lampi Island for his helpful assistance in field works. In addition, the authors are grateful to all staffs of Department of Marine Science, Myeik University, for their helpful assistance to this survey program and Filippo Maria Carli, Marine Coordinator, Fuana and Flora International (FFI), for sharing his knowledge on ecosystem services of sea grass beds. Many thanks go to Thu Rein and the staffs of the Marine Science Association, Myanmar (MSAM) for their assistance in the preparation of the manuscript. Supports for this work from Fauna \& Flora International (FFI) are most appreciated.

\section{Conflicts of interest}

We (the authors) declare that there are no conflicts of interest in relation to this article.

\section{References}

1. Green EP, Short FT. World atlas of sea grasses. UIMEP World Conservation Monitoring Centre. University of California Press. 2003.
2. Short FT, Carruthers T, Dennison W. et al. Global seagrass distribution and diversity: A bioregional model. Journal of Experimental Marine Biology and Ecology. 2007;350:3-20.

3. Fortes MD. Seagrasses: A resource unknown in the ASEAN region. ICLARM Education Series 5. International Center for Living Aquatic Resources Management. 1990.

4. Min TU, Aung MU, Kyi SU. A list of some noteworthy species of marine algae and angiosperms from the Andrew Bay, Burma. Proceedings of the Burma Research Congress. 1979.

5. Soe HU, San THU, Aye MS, et al. A summary reports on the seaweeds and seagrasses of the Myeik (Mergui) Archipelago. Tech Rep. 1997.

6. Soe HU, Mya KW, Thida N, et al. Seagrass of Myanmar with special reference to the phytogeographic distribution of the species of ASEAN nations. Journal of Myanmar Academy of Art and Science. 2009;7(5):263-387.

7. Soe HU, San THU, Mu Mu Aye, et al. Notes on seagrasses along Myanmar Coastal Regions. Kochi Univ. 2001;20:13-22.

8. Novak AB, Hines E, Kwan D, et al. Revised ranges of seagrass species in the Myeik Archipelago, Myanmar. Aquatic Botany. 2009;91:250-252.

9. Soe HU, Antt M, Salai M, et al. Seagrass conservation and monitoring in Myanmar: The biodiversity, distribution and coverage of seagrasses in the Tanintharyi and Rakhine. Bay of Bengal Large Marine Ecosystem Project (BOBLME). 2015:58.

10. Soe HU, Antt M, Salai M, et al. Seagrass surveys in the southern Rakhine Coastal Region, Myanmar: Biodiversity, distribution and coverage. $J$ Aquac Mar Biol. 2018;7(2):103-110.

11. Fortes MD, Ooi JLS, Tan YM, et al. Seagrass in Southeast Asia: A review of status and knowledge gaps, and a road map for conservation. Botanica Marina. 2018;61(3):269-288.

12. Nakaoka M, Aioi K. Growth of the seagrass Halophila ovalis at the dugong trails compared to existing within-patch variation in a Thailand intertidal flat. Marine Ecology Progress Series. 1999;184:97-103.

13. Nakahishi Y, Hosoya S, Arai N, et al. The distribution of seagrass meadows and dugong feeding trails in the dry season around Talibong Island, Trang Province, Thailand. SEASTAR.2000. 2006;13:55-62.

14. Adulyanukosol K, Poovachiranon S. Dugong (Dugong dugon) and seagrass in Thailand: present status and future challenges. Proceeding of the 3rd International Symposium. SEASTAR. 2006:41-50.

15. Soe HU, Antt M, Salai M, et al. Biodiversity, distribution and coverage of seagrasses in the Myeik Archipelago and Rakhine coastal areas, in Myanmar. J Aquac Mar Biol. 2017;6(4):164.

16. Tun T, Ilangakoon AD. Capacity building and preliminary assessment on dugong (Dugong dugon) occurrence off the Rakhine Coast of Myanmar. Report to the Society for Marine Mammalogy. 2006.

17. Burdick DM, Kendrick GA. Standards for seagrass collection, identification and sample design. In: Global Seagrass Research Methods, Short FT, Coles G, Short CA, editors. Amsterdam, The Netherlands. Elsevier Science. 2001:82-100.

18. Nakaoka M, Toyohara T. Effects of seagrass patch structure on the mobile epifaunal community in a subtidal seagrass meadow in Thailand. Benthos Research. 2000;55(2):53-61.

19. Kwak S, Klumpp DW. Temporal variation in species composition and abundance of fish and decapods of a tropical seagrass bed in Cockle Bay, North Queensland, Australia. Aquatic Botany. 2004;78(2):119-134.

20. Adam P, King RJ. Ecology of unconsolidated shores. In: Biology of marine plants, Clayton MN, King RJ, editors. Longman Australia Pty Limited, Melbourne. 1995; p. 296-309. 
21. Tuntiprapas $\mathrm{P}$, Rattanachot E, Pongparadon S, et al. The effect of seagrass coverage on swimming crabs (Portunidae) at Koh Tha Rai, Khanom-Mu Koh Talay Tai National Park, Nakorn Si Thammrat Province, Southern Thailand. Proceedings of the 6th IMT-GT UNINET Conference, Penang, Malaysia. 2008;324-329.

22. Prathep A, Rattanachot E, Tantiprapas T, et al. Seagrass Net monitoring initiative in the Southern Andaman Sea : a case study from Thailand and current studies of seagrasses in Indonesia, Malaysia and Thailand 2008. Proceedings of the 6th IMT-GT UNINET Conference, Penang, Malaysia. 2008.

23. Rattnachot E, Tantiprapas P, Wichachucherd B. et al. Seasonal variation in coverage, canopy height, fruit density and biomass of subtidal seagrass Halophila decipeins Ostenfeld in Chumphon Coast. The Gulf of Thailand. Proceedings of the 6th IMT-GT UNINET Conference, Penang, Malaysia. 2008;334-338.

24. Marcelli M, Scanu S, Frattarelli FM, et al. A benthic zonation, system as a fundamental tool for natural capital assessment in a martine environment: A case study in the northern Tyrrhenian Sea, Italy. Sustainability. 2017;10(10):1-15.

25. Den Hartog C. The seagrasses of the world. North-Holland Publishing Company. Amsterdam; 1970. 275 p.
26. Kuo J, den Hartog C. Seagrass taxonomy and identification key. In: Short FT, Coles RG, editors. Global Seagrass Research Methods. Elsevier Science. 2001;5:89-115.

27. Fortes MD. Seagrasses: Their role in marine ranching. In: Ohno M, Critchley AT, editors. Seaweed cultivation and marine ranching. Kanagawa International Fisheries Training Center Japan. International Cooperation Agency (JICA). 1993. p. 131-151.

28. Short FT, Coles RG. Global seagrass research methods. Elsevier Science BV, Amsterdam. 2001; 506 p.

29. Short FT, Mc Kenzie LJ, Coles RG, et al. Seagrass Net manual for scientific monitoring of seagrass habitat. Worldwide Edition. University of New Hampshire Publication. 2006.75 p.

30. Tun T, Barry B. Preliminary observation on the seagrasses of Lampi and neigh bouring islands of the Myeik Archipelago, Myanmar. Proceedings of the 6th International Symposium on SEASTAR2000 and Asian Biologging Science (The 10th SEASTAR workshop). Puket, Thailand. 2010. p. 85-91. 